sion to serve in various capacities of leadership: he was Treasurer of the American Historical Association (1974), 10th President of the Middle East Studies Association (1974-75), Vice-President of the Middle East Institute (1976-82) and President of the Turkish Studies Association (1980-81). He was on the Advisory Board of Editors of The Middle East Journal for 30 years from 1954.

Roderic Davison will be missed by those who knew him. His profession will miss his collegiality, generosity, humility and kindness. In his Presidential Address to MESA (November 21, 1975), Davison asked “... what is a historian of Europe who works in Turkish history doing here, in this confluence of the seas of Arabists and Persianists and Turcologists? The MESA Fellows who know me have evidently done a pretty good job of concealing my true identity. Have they been practicing taqiya on my behalf?" Rod's scholarship and professional leadership have proven that those Fellows were right.

ALAN FISHER

Michigan State University

\title{
Roderic H. Davison: An Appreciation
}

Rod Davison grew up in a happy, close-knit, academic family. They loved music and intellectual pursuits and were spiritually mature pacifists; both of his younger brothers, W. Phillips and John H. Davison, also became professors. Rod spent early teen years at Robert College, Istanbul, where his father, a Presbyterian minister later professor and dean at Auburn Seminary, taught English. Rod subsequently attended Deerfield Academy, graduated with highest honors from Princeton, and earned his $\mathrm{PhD}$ in History under William Langer at Harvard in 1942. His magisterial thesis on Reform in the Ottoman Empire, 1856-1876, was revised and published in 1963 with a second edition in 1973.

The depression and experiences in Europe 1935-44 opened horizons that Rod enlarged throughout an exemplary life. During the Spanish Civil War, he and three French hiking friends became lost in a Pyrenees fog and were facing execution as alleged spies in a Barcelona prison in 1937. They were ransomed after two months by the French consul, who assured passportless, penniless, grateful Rod that he acted “...pour l'honneur de la France!” Rod knew Europe, French, German and Turkish well and learned some Greek and Serbo-Croatian. He studied at the University of Nancy and led Experiment in International Living groups in France and in Germany in the summers of 1935, 1937 and 1938, thereby enlarging his vast repertoire of classical and folk songs, opera and hymns. World War II interrupted his doctoral research in Paris and Vienna and plans for more in Turkey. He accepted an instructorship at Princeton, where he completed his dissertation and helped to revive the Friends Meeting, 1940-42. Rod inspired trust and evoked good in everyone he met.

He returned to Vichy France in 1942 as a pacifist American Friends Service Committee volunteer assisting Jewish refugees while his father headed the Presbyterian Peace Fellowship. Interned by the Germans in the Brenner Park Hotel in Baden-Baden in early 1943, Rod helped organize a university and taught 
history to internees. Repatriated in 1944 (he joked that he was valued at one-anda-half German exchangees), he did soil conservation at Big Flats, NY, Civilian Public Service Camp, where associates elected him Camp Director. Rod completed wartime alternative service as historian of the National Service Board of Religious Objectors in Washington, then returned to Princeton again as Instructor in History before appointment as Assistant Professor at George Washington University in 1947, where he spent the rest of his illustrious career.

Rod believed that "there's no such thing as diplomatic history" only analysis of the socio-political, economic matrix from which policy evolves. His studies illuminated that context so masterfully that "Toynbee cited him 18 times before Rod was forty," according to Ronald Thompson, a GW colleague. A Turkish doctoral student of his writes that, "For any research on diplomatic history his main advice was to look at the subject from the inside out and not the other way around."

Davison was among some 16 founders of the Middle East Studies Association in 1966 and one of the seven organizers of the Turkish Studies Association at our Denver MESA meeting in 1971. When offered the Presidency, he declined, observing wisely that we should choose a Turkish-American scholar first. Kemal H. Karpat was then elected unanimously, and Rod was our TSA President later.

He mentored many prominent scholars and diplomats. Like Chaucer's scholar, he would "gladly learn and gladly teach." Malcolm Kerr, murdered President of MESA and the American University of Beirut, was, as many, first student, then friend. Rod, former tennis and soccer champion, seldom followed sports, but in recent years would check sports pages for the scores of Steve Kerr, a Chicago Bulls national basketball champion and one of Ann and Malcolm Kerr's five children. Mrs. Nur Bilge Criss earned her PhD under Rod in 1990. In an impressive Turkish edition of her thesis, Istanbul During the Allied Occupation, 1918-1923 (Istanbul, 1993), she expresses her "gratitude to Dr. Roderic H. Davison who not only encouraged me to undertake this study, but also stood by me throughout the whole ordeal despite the physical distance between us" (p. xiii). Now Associate Professor of International Relations at Bilkent University, she wrote in 1984: "Although Dr. Davison has left an indelible mark on 19th century Ottoman History... (He of course would be the last one to admit this) it is not only the quality of his works, but the spirit in which they are written that are worthy of note..." She adds, in a recent letter:

After I was awarded a $\mathrm{PhD}$, Professor Davison said, "Now that we are colleagues, you should call me Rod." That was out of the question. After lengthy deliberation we settled on "Maestro." So, I will refer to Maestro, the human being and friend first. We could not be more different-Maestro so frugal, I the opposite, Maestro spiritual, I worldly. He called himself an "Old Turk" and myself a "Young Turk," and there was more truth to it than just our chronological difference. Love for and fascination with Istanbul were some of the common things we had. A daily excursion on the Bosphorus, late lunch at Anadolu Kavağı, dinners at Haci Baba, his favorite restaurant in Siraserviler are only but some memories of last summer. I found him to be a charming and humorous 
companion and an excellent host... after... a long day's work at the archives... It was just as charming when he played the piano after dinner...

Professor Davison's inspiration is there behind all my publications... He was kind enough to indulge me when I became involved in current history... But he was happier when I delivered a paper on the Ottoman Feminists in Heidelberg last July (1995) [at the VIIth International Congress on Ottoman Economic and Social History, 1300-1920], happy enough to attend an 8:30 am session. "Good to see that you are doing history again," he said. Lastly, I was honored by the OAH's [Organization of American Historians] The Journal of American History, to become a contributing editor from Turkey in 1996. Maestro had served as treasurer of the American Historical Association in the past. It is of particular pride and joy that I consider this occasion yet another fortunate event when our lives touched.

Professor Bilge Criss concludes with the most welcome and touching news that "the Türk Tarih Kurumu [Turkish Historical Society, founded by Atatürk] awarded Honorary Membership to Professor Davison yesterday" [June 12, 1996].

Our MESA colleague Professor Peter Bechtold, Director of the Foreign Service Institute, reports that Rod's FSI lectures, full of insight and humor, were perennially popular and that he always benefitted from them. Rod became a Distinguished Lecturer at FSI. He also earned the Chairman's Award in Education from the American Friends of Turkey.

Rod's self-esteem, wit and sensitivity tendered and enlivened many encounters. When the University Senate debated reducing the foreign language requirements for the PhD, Davison demurred, speaking first in English, then in fluent French, next in flawless German and concluding in English to illustrate his point. Rod was elected to the University Senate eight times; he chaired its Executive Committee, the History Department twice, served as Acting Dean of the Graduate School and on numerous university committees over forty years of unrivalled dedication. The Senate Minute adopted on his 1986 retirement (he continued to teach until 1993) concludes: "The statistics of his accomplishments and services, however, hardly do justice to Rod Davison's personal qualities, so highly valued by his colleagues in the department and throughout the University. His gentleness of manner, his quick understanding, his ethical insights, his questioning mind and, above all, his warm collegiality and world-class abilities to act as conciliator will be sorely missed."

Awarded an Honorary Doctorate of Humane Letters by George Washington University in 1994, Rod maintained his varied interests. He attended international scholarly conferences in Europe in 1994 and 1995, revisiting Turkey and the Brenner Park Hotel in Baden-Baden, where he was welcomed as a celebrity by surviving staff he'd met in 1943. With typical generosity he invited some of us attending the 1995 MESA meeting in Washington to his ever hospitable Lowell Street home for dinner. He completed an article on the "Tanzimat" for The Encyclopaedia of Islam in hospital early in 1996. He remembered Robert College and Turkey in his will. 
In addition, Rod served for many years on the boards and key committees of some twenty organizations such as the American Friends Service Committee, American Peace Society, the Fulbright and Cross Cultural Fellowship Programs, Hazen Foundation, International Student House in Washington, the Conference on Peace Research in History, Society for Values in Higher Education and the American Research Institute in Turkey.

Rod's spiritual home was the unprogrammed Florida Avenue Friends Meeting in Washington, where a meeting in his memory gathered on April 27, 1996. It would have been his 80 th birthday. He was a Meeting Trustee active on various committees, most recently the Friends Club, where he sang and played the accordion or piano to uplift Alzheimers patients. Fifty years before, he'd board New York-to-Washington trains, finger his accordion and call out "Now SING everybody!" to the astonished enjoyment of fellow passengers soon singing along with him.

Rod married Louise Atherton Dickey, who received bachelors and masters degrees in archeology from Bryn Mawr. She worked in government, on the Vestry of St. Albans Church and was an officer of the Washington chapter of the Archeological Institute of America, museum docent and gracious hostess. She and Rod had two sons, R. John and Richard H. Louise died in 1991.

Youngsters delighted Rod, who wrote last Christmas that he found his grandchildren, Thomas John, four-and-a-half, and Kathryn Louise, one-and-ahalf, "eminently satisfactory." His brother John, fourteen year's Rod's junior, found him "admirable, a perfectionist, yet always comforting and supportive when needed, like a big tree you climb and take refuge in." Rod is in truth, to paraphrase Beethoven, "the immortal beloved" to each of us whose lives he touched for the better.

HOWARD A. REED

The University of Connecticut

Nazih Nassif Mikhail Ayubi was born December 22, 1944, in Cairo; he died December 4, 1995, in Exeter, leaving a wife, Rosalind, and a son, Sami.

It is with great sadness that we convey news of the death of Nazih Ayubi. His intellectual contribution to the study of the Middle East was formidable. His breadth of knowledge, his personal commitment and the force and clarity with which he expressed his views left an indelible impression on all who were fortunate enough to learn from him. His tragically early death, at the age of 50, has cost the discipline of Middle East Politics one of its most profound thinkers. The depth of that loss can be appreciated through the caliber of Nazih's books such as Political Islam (1991), which consolidated his reputation as a subtle and original student of Islamic political theory. But towering over even such influential works was the study in which he took most pride, his magisterial Over-Stating the Arab State (1995), which promises to establish itself as a classic treatment of the politics of the Arab world.

Nazih was born in Egypt, where he held his first academic posts before taking an Oxford doctorate and a professorship at Cairo University. He moved 